\title{
Qualitative Analysis of Visual Data in Information Behavior Research
}

\author{
Sabina Cisek \\ ORCID 0000-0002-2877-752X \\ Monika Krakowska \\ ORCID 0000-0002-2724-9880 \\ Faculty of Management and Social Communication \\ Jagiellonian University in Kraków, Poland
}

\begin{abstract}
Purpose/Thesis: The paper contains a methodological reflection on qualitative analysis of visual empirical data as a research procedure in the contemporary human information behavior research. The possibility of implementing this approach has been tested on a case study of personalized information spaces in everyday life of undergraduate information management students in the academic year 2018/2019.

Approach/Methods: The reported research employs the realist epistemological stance, qualitative and descriptive approaches, and four methods/techniques: critical literature review, case study, drawing as a mental mapping tool, and thematic analysis.

Results and conclusions: Visual data analysis is cognitively fruitful; it enables grasping the multidimensional "information reality" as perceived by the users (the humanistic coefficient). However, it is time-consuming, it requires meticulousness and self-reflection on the part of the researcher; it must also leave a clear audit trail to assure credibility and intersubjective verifiability of investigations.

Originality/Value: The article is concerned with innovative research procedures, rarely discussed in Polish information science literature. Combining visual approach with individual information spaces, it corresponds to the latest methodological and topical trends in the field of information behavior. It also links theoretical reflection with the research practice.
\end{abstract}

Keywords

Arts-based methods. Drawings. Information behavior. Information spaces. Mental models. Methodology. Qualitative analysis. Thematic analysis. Visual data. Visual research.

Received: 9 June 2019. Reviewed: 17 June 2019. Accepted: 12 July 2019.

\section{Introduction}

The focus of this paper is a methodological reflection on qualitative analysis of visual empirical data as a research procedure in the contemporary human information behavior research (HIB). The article consists of two parts, where additional, more specific questions are raised. In the first chapter we depict the functioning of visual approach and data in the HIB area in the 21st century, relying on the critical review of relevant English language literature from years 2001-2019. In the second part, we present a case study of mental models of individual information spaces in everyday life, employing visual data in the form 
of participant-generated content (drawings). The primary intention of this empirical project was to test how visual approach "works" in research practice (e.g. by what methods visual data may be collected and analyzed), and to determine what are scholarly advantages and methodological or executional challenges of such an approach. The additional aim has been to explore how the abovementioned mental models are constructed and how they may vary.

However, our suggestions are only tentative, as we recognize that the full and multidimensional picture of those phenomena awaits further intensive analysis. Terms "information behavior" and "human information behavior" are used here interchangeably and understood broadly, according to the present trends in library and information science. Thus, as Case \& Given write

\begin{abstract}
information behavior (...) encompasses information seeking as well as the totality of other unintentional or serendipitous behaviors (such as glimpsing or encountering information), as well as purposive behaviors that do not involve seeking, such as actively avoiding information". The term also includes broader context of how individuals 'deal with' information in their lives, so accounts for situation, time, affect, culture, geography, and other contextual elements in understanding people's IB (Case \& Given, 2016, 6).
\end{abstract}

Furthermore, following Fisher et al.

we conceptualize information behavior as including how people need, seek, manage, give, and use information in different contexts (Fisher et al., 2005, XIX).

For the discussion of other concepts and terms important for this paper, i.e. information spaces, mental models and, of course, visual data/research, see sections 2 and 3.2 below.

We have employed four research methods/techniques in our study: critical literature review (Cisek, 2010), case study (Blatter, 2008), drawing as a mental mapping technique (Cox \& Benson, 2017; Mitchell et al., 2011), and thematic analysis (Ayres, 2008; Braun \& Clarke, 2012; Braun et al., 2019). A more detailed description of the listed procedures is given in sections 2 and 3.3 of this article. In general, our research is qualitative, descriptive and exploratory; it makes an introduction to further, in-depth investigations, which would be more explanatory and interpretative.

In addition, we want to make clear that our focus is on qualitative analysis of empirical visual data, rather than on visual analysis of qualitative data, or on problems of data visualization, as these issues are beyond the scope of this paper.

\title{
2. Visual data in the information behavior research
}

We conducted a critical literature review to determine the state of development of visual data analysis within the HIB field. In May 2019, we searched the LISTA, SCOPUS and SSCI/Web of Knowledge databases with combination of phrases "information behavior", "information needs", "information practice", "information seeking", "information sharing" and "visual approach/data/method/research/strategy", applying no limitations. After eliminating duplicates and supplementing the results by the snowballing technique we received roughly 40 relevant publications, all of them from the 21st century. The works relevant to our study were based on empirical visual data of various types (i.e. they collected and analyzed visual material for a purpose of a given research) and/or contained associated 
methodological reflection. However, this may not be a complete picture, because the authors do not always clearly describe their methods and techniques (Pollak, 2017, 99), as well as owing to terminological vagueness (see below).

Furthermore, there is another set of publications employing empirical visual data, mainly in the form of participant-generated diagrams and drawings, which does not use explicitly the term "visual". The papers from this group primarily concern users' conceptualizations and mental models of computers, Internet/Web, information retrieval systems (e.g. selected databases), institutional repositories, libraries and search engines (Google). A comprehensive literature review of this line of inquiry, along with its accomplishments and pitfalls, may be found in (Kodama et al., 2017). Image-related techniques were applied much earlier in this area of information science than in the "mainstream" HIB research. Kodama and others explain that

studies of users' mental models have become increasingly prevalent over the past 30 years or so and drawing, in particular, has been used to elicit adults' and children's mental models for both research and instructional purposes (Kodama et al., 2017, 409).

The visual research as such, understood as focusing on creation, organization and interpretation of imagery, has been employed as a part of both qualitative and quantitative strategies in social sciences since the 1960s (Hicks \& Lloyd, 2018). At present, visual approach, as has already been reported in the literature, is becoming increasingly important for information science, e.g. in the qualitative information behavior research (Greyson, et al., 2017; Hicks \& Lloyd, 2018; Pollak, 2017). Visual methods are considered to be both alternative and innovative, as well as human-centered, and therefore showcasing the participants' own voices rather than the researchers' presumptions (Hicks \& Lloyd, 2018). This is specific to the qualitative strategy (Cisek, 2013). Most of the visual-based empirical studies in HIB have been conducted in the 21st century, starting with the work of Sonnenwald et alia (2001), which used visual mapping of students' information horizons - an approach similar to the one we take in this paper. Additionally, few contemporary information science publications offer at least partial reviews of the relevant literature and give the idea of "the state of knowledge" as far as visual research in the information behavior is concerned, including meta-level methodological consideration of that approach. Among these are works of Greyson, O’Brien and Shankar (2019), Hartel (2014a; 2017), Hartel and Thomson (2011), Hicks (2018), Hicks and Lloyd (2018), Pollak (2017), and others.

According to Pollak, in general, visual research is

understood to include collecting, producing, organizing, and interpreting imagery in all its various forms for research purposes (Pollak, 2017, 98).

However, as the cited author goes on to argue,

beyond a basic definition of what visual means, (...) there is little consensus among researchers about what the options are, or when, how, or why to use them" (Pollak, 2017, 98).

Furthermore, there are terminological inconsistences within that area of information behavior. Authors use various terms, whose scope of reference is identical or only slightly different, such as "arts-based methods/research" (Cox \& Benson, 2017), "arts-informed approach/methodology/research" (Hartel, 2014a), "image-based methodologies" (Hicks 
\& Lloyd, 2018), "visual approach" (Hartel \& Thomson, 2011), "visual methodology" (Hartel, 2017), "visual methods" (Hicks and Lloyd, 2018), and the like. Furthermore, the visual method may be understood either broadly, as a strategy steering the entire research design, or narrowly, as one of the available data gathering techniques, often enriching the verbal ones - interviews, focus groups, diaries, as well as experiments and observation (Greyson et al., 2017, 149-150; Hartel \& Thomson, 2011, 2215).

Nevertheless, one important conclusion needs to be stated - in the analyzed qualitative information behavior literature the adjective "visual" always indicates, that empirical visual data/material was collected and used for a given study, despite methodological, theoretical or topical differences. Visual data is also called "imagery" (Pollak, 2017), "images" (Hartel, 2014a), "visual representations" (Hartel, 2017), and "pictorial metaphors/representations" (Hartel \& Savolainen, 2016).

The question becomes then, what makes the qualitative visual data? When gathering visual empirical material for a research project, as with any other type of data, we frequently face a twofold choice between using already existing material and producing new one, created as a result of our intervention (Siegesmund, 2008). Both methods are seen in the qualitative HIB area. Thus, we have participant-generated data, researcher-generated material, or use of already existing content, e.g. photos or videos shared on the social media. The participant-created (also - art-based or creative) content may take forms of cartoons, collages, diagrams, drawings, films, mental maps (catching spatial conceptualizations), photography, pictures, schemes, sketches, sculpture, and timelines (capturing temporal experience) (Hartel \& Thomson, 2011; Hicks \& Lloyd, 2018; Pollak, 2017; Zhang, 2008, and more).

Visual data has been generated for the information behavior studies by following research procedures:

- the draw-and-write technique (Hartel, 2014a; 2014b);

- graphic/visual elicitation methods, e.g. drawings or timelines, which use images "to drive interview discussion" (Hicks \& Lloyd, 2018, 231), "to represent mental models" or "to solicit people's conceptualization” (Zhang, 2008, 1331);

- the information horizon interview (Sonnenwald et al., 2001) - "the first and currently best-established visual method for the study of information behaviour" (Hartel, 2017);

- photo-elicitation methods, e.g. the photo-diaries and photovoice (Hartel \& Tomson, 2011; Hicks \& Lloyd, 2018);

- IWM - the information world mapping (Greyson et al., 2019);

- $\quad$ and even the information mapping board game (Le Louvier \& Innocenti, 2019).

Imagery may be analyzed by various qualitative techniques: compositional interpretation, conceptual analysis, grounded theory approach, pictorial metaphor analysis, thematic analysis, and visual discourse analysis - situational analysis (Greyson et al., 2019; Hartel, 2014b; Hartel \& Savolainen, 2016; Hicks, 2018).

Additionally, Cox and Benson note that

much of the interest in visual methods is tied to a concern with the everyday and embodied experience, to ways of experiencing the world beyond text and talk: the other senses, emotion and imagination (...). Techniques such as drawing recognize the importance of this and respect different forms of knowing (Cox \& Benson, 2017). 


\section{Mental models of personalized information spaces in everyday life - a case study of the information management undergraduate students}

\subsection{Research goals and problems}

The empirical research in the form of a case study aimed to find out how a group of students of information management perceived and conceptualized their personal information spaces in everyday life; in other words - what were their mental models of those spaces. But, as it has already been mentioned in the introduction, our analysis was primarily directed by meta-methodological questions regarding employing visual data in information behavior research. The use of such material requires a theoretical framework, as well as methods of visual data gathering and qualitative analysis. These three elements are strongly interconnected, and need to be clearly articulated, not only to confirm the research reliability, but also simply to make sense of the findings, as from the qualitative standpoint human behavior is understandable only in its context (Cisek, 2013). As Cox and Benson argue,

good qualitative research should be honest and authentic about its aims, methods, biases, limitations, successes and failures,

even if

there is no reason to think visual methods (in themselves) allow for greater self-reflexivity in the research, although they may encourage greater reflexivity on the part of the participant (Cox \& Benson, 2017).

\subsection{Theoretical framework}

In the human information behavior area, there is no commonly agreed understanding of the term "information space". The researchers of HIB take various approaches and use different spatial metaphors, including conceptual geographies (Greyson et al., 2017), information fields (Johnson, 2003), information grounds (Fisher \& Naumer, 2006), information horizons (Sonnenwald, 2005), immediate information spaces or personal information environments (Hartel \& Thomson, 2011), information use environments (Taylor, 1991), information worlds (Burnett \& Jaeger, 2011), small worlds (Chatman, 1991; Savolainen, 2009), and other concepts related to information ecology (Babik, 2014). Information space may be seen from different perspectives, i.e. informational, cognitive, affective and socio-cultural ones. It is frequently understood as a specific human environment in which various responses to external and internal stimuli take place, and where the user undertakes a variety of information activities (Yu, 2011; Burnett \& Jaeger, 2011). There are many dynamic relationships in the information space, where the surroundings are subjected to a continuous interpretation and provoke emotional reactions, related to human information activities, processes and behaviors (Savolainen, 2009). In this paper, we use terms "individual information space" and "personalized information space" interchangeably.

A personalized and multi-dimensional information space, consisting of and generated by specific and interrelated spatial, physical, abstract and symbolic elements, may be analyzed from many perspectives. For example, the technological approach allows understanding the information space as a system with a set of various sources, real and virtual objects, the 
needs and the potential of an individual, as well as information organization (Cole \& Leide, 2003; Krishman \& Jones, 2005; Kisilowska, 2011).

According to the normative point of view, human information space is conditioned by several social determinants, such as norms, relations, roles, values, their functions in interactions with the environment and their impact on information processes and behavior. This perspective is based on the concepts of Chatman's small worlds (Chatman, 1991; Savolainen, 2009), Sonnenwald's information horizons (2005), as well as Fisher's information grounds (Fisher \& Naumer, 2006), among others.

The information space explored from the affective perspective is considered in relation to the emotional factors, mood, personality, as well as to the genetic aptitudes, which might be represented by the abovementioned theoretical models of Chatman, Sonnenwald and Fisher.

The cognitive optics for analyzing individual information spaces allows determining the significance of thought processes, metaphorization or cognitive structures. Additionally, this approach draws attention to the role of mental models, specific structures of knowledge, as well as to mastery and way of life as conceptualized by Savolainen (2005) and sense making as theorized by Dervin (2005). Thus, the cognitive approach to personalized information spaces provides an opportunity to analyze the influence of mental representations that allow the users who constructed them in their minds to participate in various interactions with the internal and external environments. These mental structures, built as prototypes, help in functioning, assimilating and adapting to the information space, moving around in the information environment, understanding the context and making sense of reality (Zhang, 2008).

Mental models (representations) have been studied in information science since the 1980s. Generally speaking, they are

knowledge structures that people employ to represent, make sense of, and interact with the external world (Zhang, 2010, 2206).

Mental models establish substrates for understanding the reality, objects, systems, even though they are impermanent, individual, subjective, and dependent on a specific situation and the individual's knowledge (Johnson-Laird, 2010). These non-verbal and usually iconic imitations constructed in the mind are internally visualized, exploratory and comparative patterns of the surrounding world. They explain or imitate components of the surrounding space, including information environments and objects, phenomena, events, processes; they might also be defined as cognitive/knowledge structures or cognitive/knowledge states (Chen \& Ke, 2014). Mental models may initiate various information behaviors/processes; additionally, they activate perceptual and motor knowledge in an individual. It is worth noting that people do not only use these internal cognitive structures to understand their worlds, but also to gain the more superior sense and reference, which in turn shapes a variety of information actions/practices (Bergen, 2015; Kerkhofs \& Haselager, 2006).

Mental models may be categorized using different criteria. They are "extracted" from the internal intellectual structure of a human being through a variety of research techniques, including graphic elicitation or mental mapping. Various attempts to classify mental representations were already made in the HIB field, e.g. by Zhang (2008), Cole and co-researchers (Cole \& Leide, 2003; Cole et al., 2007), Holman (2011), Engelhardt (2002), and Hartel and Savolainen (2016). 
Zhang's categorization of mental models (elicited from participants' drawings, among others) allows an analysis from four different perspectives:

- the technical view, in which the most important elements relate to system components, tools, information and communication resources, individual objects, and users co-creating a space or a system and functioning in it;

- the functional view, representing a variety of information activities/behaviors;

- the process view, in which the information space is an area of various information management processes, e.g. collection, analysis and transformation; this view considers the impact of these processes on individual elements constituting the information structure of the environment;

- the connection view, focusing on dependencies and specificity of connections between particular elements, which are the result of processes carried on and activities undertaken as a part of wider information behavior (Zhang, 2008).

Cole and co-researchers (Cole et al., 2007) established two general classes of mental models, which were based on their evaluation of pictorial representations (diagrams): (1) horizontal, with more layers/objects in horizontal dimension, and (2) vertical, with more layers/objects in vertical dimension. They analyzed individual layers, structures, elements, and zones represented in the drawings. They used the concept of anomalous states of knowledge (ASK) proposed by Belkin and Kwasnik, who identified four facets of the ASK structural representations, the combinations of which determine the method and order of application of basic ranking strategies in information behavior (Belkin \& Kwasnik, 1986). This approach allowed Cole and others to develop more specific mental models, such as:

- equal scheme with equal layers/objects in both vertical and horizontal dimension;

- cluster scheme with more than one concept zone, grouped or linked together;

- star scheme with one significant concept that radiates out to other less important concepts, categories, objects to random directions;

- nested scheme where concepts are located within other concepts or ideas/themes;

- tree branch scheme that would be vertical or horizontal and starts with one concept branching subsidiary concepts or themes, objects, ideas.

Moreover, Cole et al. distinguished complementary mixed mental models, combining previously identified types in drawing representations, such as: nested and star, star and cluster, horizontal and tree, nested and vertical, nested and horizontal (Cole et al., 2007).

Analyzing the existing examples of visual data, Engelhardt found two basic types of drawings and cognitive representations: primary and hybrid. He identified a map, picture, statistical chart, time chart, link diagram, grouping diagram, table (composite), symbol and written text as primary types, and a statistical map, path map, statistical path map, statistical time chart, statistical link diagram and chronological link diagram as hybrid types (Engelhardt, 2002, 137). Engelhardt's detailed examples of different categories of mental models and their expression through pictorial metaphors, especially in the context of understanding information and information sources, allowed to specify the following types of graphic representations: (1) link diagrams, (2) grouping diagrams, (3) texts, (4) abstract patterns, (5) ambiguous images, (6) blanks, and (7) information artifacts, activities or technologies (Engelhardt, 2002; Hartel \& Savolainen, 2016). This typology was the foundation of qualitative analysis of information visualization in the socio-psychological perspective, proposed by Hartel and Savolainen (2016). Basing their research on graphic elicitation (the 
specific drawings called iSquares), they have distinguished several mental representations of information - the Earth, a web, a tree, a bulb light, a box, a cloud, a seeding, a sun, sea, a dot, mountains, path or journey, city and fishing or mining (Hartel \& Savolainen, 2016).

\subsection{Methodology}

To collect empirical data, we used a convenience sample, i.e.

a sample in which research participants are selected based on their ease of availability (Given \& Saumure, 2008, 124).

Thus, the first-year full-time undergraduate students of information management at the Institute of Information Studies (then the Institute of Information and Library Science) of the Jagiellonian University in Kraków formed a group of our study members in October 2018. Without any prior theoretical introduction, they were asked to draw on a piece of paper an image that would represent their understanding of their own, personalized information spaces. The task was completely anonymous, non-mandatory and spontaneous. Thanks to this participatory arts-based technique (Greyson et al., 2019, 1) 63 pictorial representations of the students' individual information spaces were collected, giving us rich empirical material for the subsequent qualitative analysis (with some quantitative elements). It is also worth underlining that information science often makes use of drawings as a technique to elicit mental models of various kinds. As Zhang writes,

drawings are illustrative in demonstrating the elements included in mental models (Zhang, 2010, 2207).

The analysis was twofold. First, we examined the obtained drawings in the light of categorizations of information-related mental models existing in the information behavior area, including those by Zhang (2008), Cole et al. (2007), Engelhardt (2002), as well as Hartel and Savolainen (2016) (see section 3.2 above). This analysis was tentative and intended primarily as the first phase of a possible future research. Its central goal was to check if there were any relations between results of our and previous investigations and to confirm that it allowed for (at least middle-range) generalizations.

Secondly, we conducted the thematic analysis (TA) of a set of pictorial representations. Thematic analysis as such is not, as Braun and Clarke state,

a single qualitative analytic approach. It is better understood as an umbrella term, designating sometimes quite different approaches aimed at identifying patterns ("themes") across qualitative datasets (Braun et al., 2019, 844).

There are three main types of TA: codebook, coding reliability, and reflexive. We have chosen the third type because of its flexibility, non-idiographic style and "pure" qualitative nature, which meant that both data collection and analysis were underpinned by the qualitative paradigm. The reflexive thematic analysis consists of the following phases: familiarization with the data; generating codes - inductively, deductively (theoretically) or by combination of both strategies; constructing themes (eliciting patterns across the data set); revising and defining themes; and producing the report (Braun \& Clarke, 2006; Braun \& Clarke, 2012; Braun et al., 2019). In our research, we applied a mixture of inductive and deductive/theoretical forms of reflexive TA. Therefore, coding was based not only on 
the collected visual data as such but also on the existing theories of information behavior, focusing on the concepts of information grounds (Fisher \& Naumer, 2006) - in particular the trichotomy people-places-information, information horizons (Sonnenwald, 1999; 2005), and small worlds (Chatman, 1991; Savolainen, 2009). Thus, the codes concerned the following components of the students' individual information spaces: people, places, information sources, both documentary and human, information activities/processes, and selected affective and socio-cultural factors, including values. In addition, as in the Hartel's research,

the drawings were seen in a realist (...) manner that embraced their surface reality, rather than their socially constructed, latent or metaphorical meanings (Hartel, 2014b).

To sum up, the reported study has taken the realist epistemological stance; it was qualitative and descriptive, i.e. it prioritized the identification of components and forms of mental models of individual information spaces, but did not seek a deeper explanation and interpretation of their causes, conditions, context, functions, etc. This we leave to the future research, more interdisciplinary in nature.

\section{Results (selected)}

The students' pictures have made for great set of rich, multifaceted empirical material. Among the 63 drawings, 9 are pure graphic items, 21 - prevailing text - verbal mental maps, and 33 - mixed text and graphic representations. In addition, within all the pictures there are 10 mostly abstract representations, such as a futuristic head resembling a spaceship, a café or an idyllic landscape. The verbal content of all but one of the items is in Polish, because it was the language used by our study participants (with just one exception).

As it has already been suggested in section 3.3, a detailed analysis of individual components and their configurations occurring in 63 drawings allowed for identifying various types of mental models. Subsequently, the pictorial representations of those models have been assigned to different categories, as proposed by Zhang (2008), Cole and others (Cole \& Leide, 2003; Cole et al., 2007), Engelhardt (2002), and Hartel and Savolainen (2016).

Secondly, as a part of the thematic analysis, codes were attributed to all elements presented in the drawings, both textual and graphical. Then, these elements were categorized according to their influence on the individual information spaces they constituted. The formation of the affective and social dimensions was analyzed in reference to the theoretical frameworks of information horizons, information grounds, and small words (Chatman, 1991; Fisher \& Naumer, 2006; Hartel, Oh \& Nguyen, 2018; Sonnenwald, 1999; 2005).

With reference to the categorization of mental models adopted by Zhang, 23 drawings gave a technical view of information spaces (Fig. 1), where elements of information spaces, resources, artifacts concerning places or people important for the users were specified. 


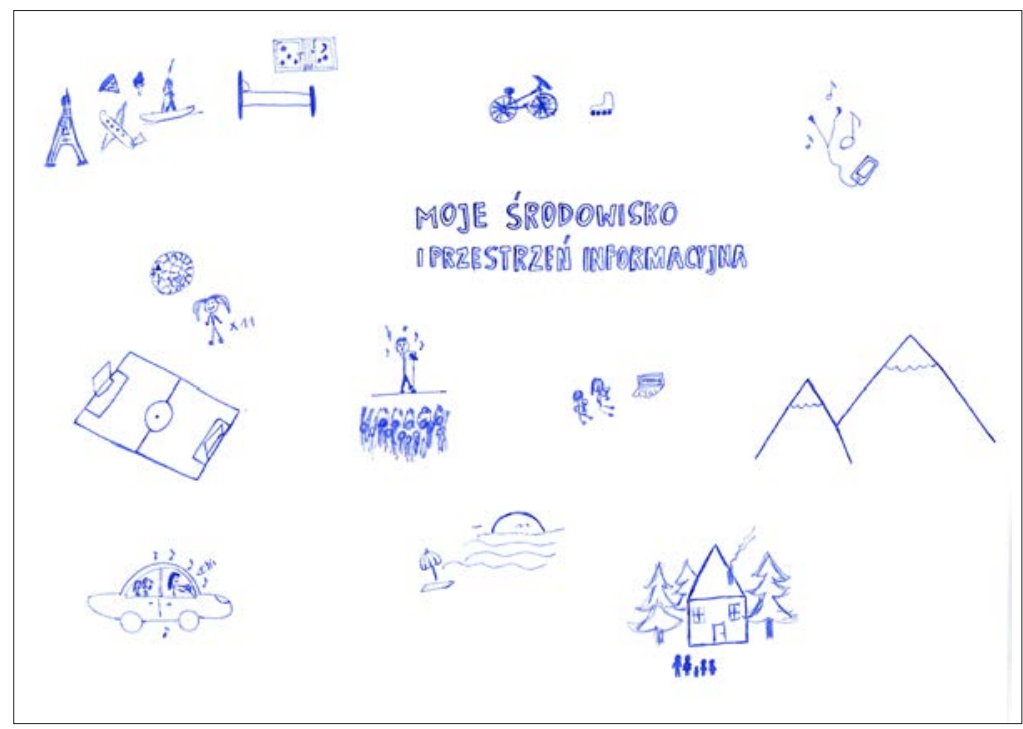

Fig. 1. An example of Zhang's technical view of cognitive representation of individual information spaces [The central inscription translates to: "My environment and information space"]

Seventeen pictorial representations, the example of which is shown below, expressed the functional view of information space, which prioritized the different functions of communication and information processes. The students paid attention to types of individual and group information behavior, such as information searching, encountering or sharing.

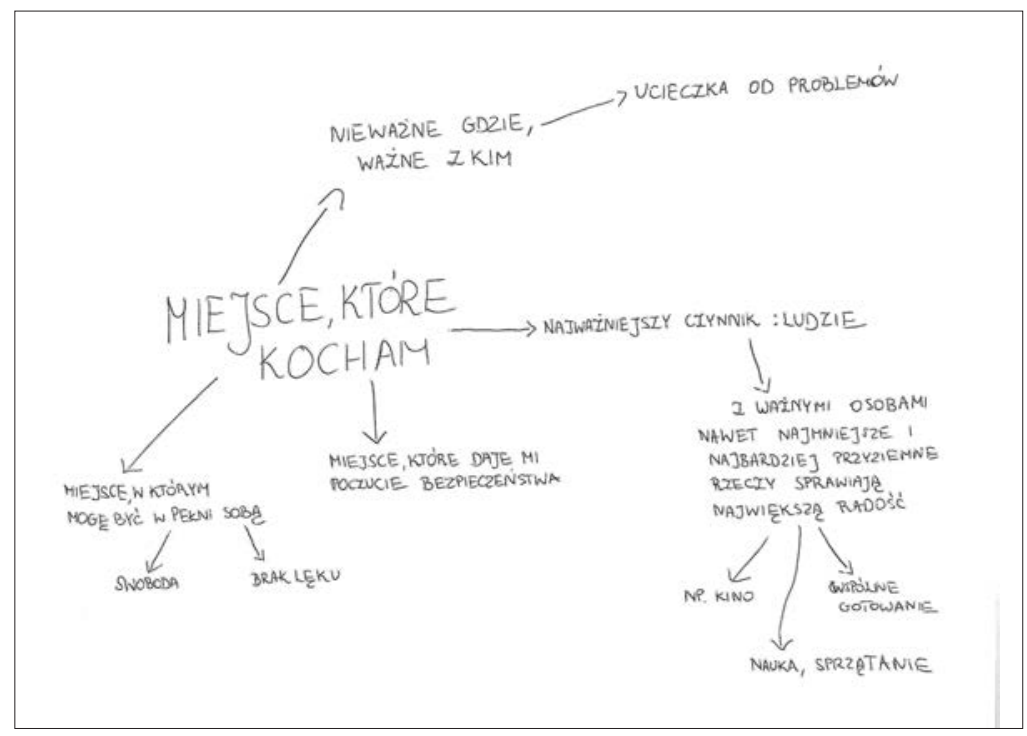

Fig. 2. An example of Zhang's functional view of cognitive representation of individual information spaces 

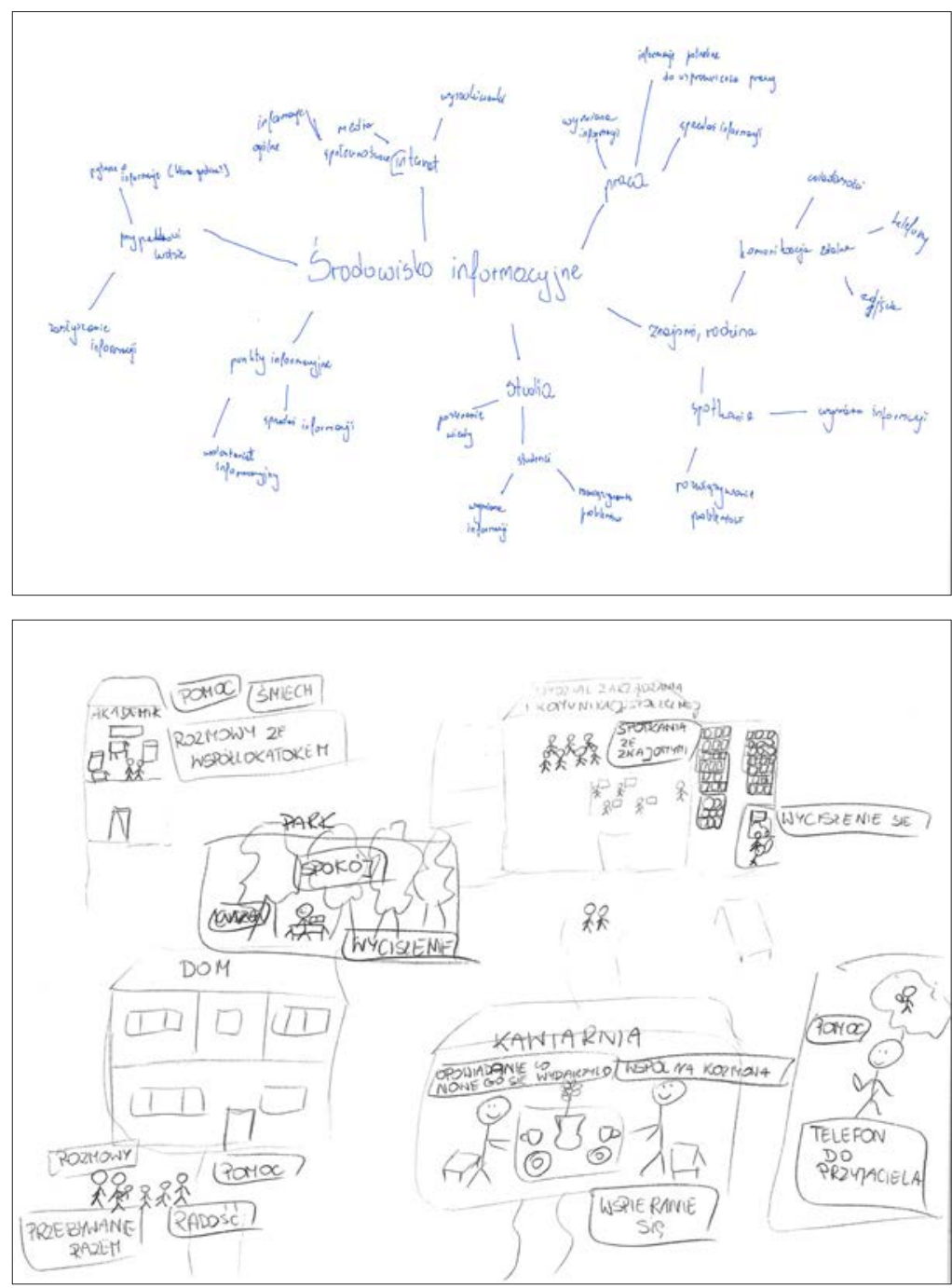

Fig. 3. The examples of Zhang's process and connection views of cognitive representation of individual information spaces

Twelve drawings demonstrated the process view with various transformations taking place in the information space, treated as the area of multiple information processes, related to each other, as well as to persons, places and sources. Only 11 pictures represented the connection view indicating the various connections between people and information resources. The examples of mental representations in the connection and process views according to Zhang are given in Figure 3.

Of 12 categories of mental models as proposed by Cole et alia, which describe various layers, grouping of areas, visualizing processes, relationships between individual components of visualized mental models, 11 categories were assigned to the collected pictures. 
These were: cluster (16 drawings), star (15 drawings), star and cluster (11 drawings), nested and horizontal (5 drawings), horizontal and tree (4 drawings), nested (4 drawings), horizontal (3 drawings), equal ( 2 drawings), etc. (see Table 1$)$. There was no representation of the vertical mental model of information space.

Tab. 1. Representation of Cole et al's categories of mental models among the collected drawings

\begin{tabular}{|c|c|c|c|c|c|c|c|c|c|c|c|c|}
\hline & $\begin{array}{l}\tilde{U} \\
\stackrel{\Xi}{\Xi} \\
\text { Ũ }\end{array}$ & సే & 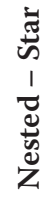 & 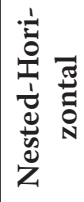 & 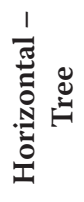 & $\begin{array}{l}\widetilde{D} \\
\tilde{D} \\
\tilde{z}\end{array}$ & 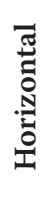 & $\underset{\widetilde{Z}}{\widetilde{Z}}$ & 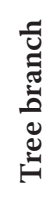 & 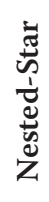 & 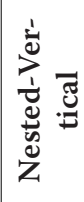 & 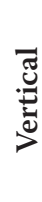 \\
\hline $\begin{array}{c}\text { Number of } \\
\text { drawings }\end{array}$ & 16 & 15 & 11 & 5 & 4 & 4 & 3 & 2 & 1 & 1 & 1 & 0 \\
\hline
\end{tabular}

The representation of Engelhardt's categories in the gathered images is shown below in Table 2. Among the 63 drawings, we identified 38 purely graphic representations of information activities and technologies, 24 mixed drawings, which included both text and graphics, 22 purely verbal representations, 17 pure graphic diagrams, 3 ambiguous images and 2 examples of exceptionally surreal drawings, e.g. the information space as a head-spacecraft.

Tab. 2. Engelhardt's categories of mental models - number of visual representations

\begin{tabular}{|c|c|c|c|c|c|c|c|}
\hline & 占 & 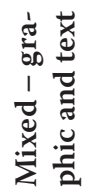 & 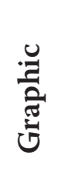 & 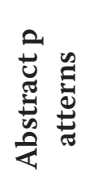 & 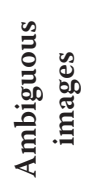 & $\frac{\ddot{\theta}}{\tilde{\tilde{E}}}$ & 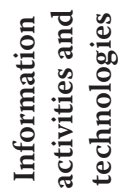 \\
\hline $\begin{array}{l}\text { Number of } \\
\text { drawings }\end{array}$ & 22 & 24 & 17 & 2 & 3 & 0 & 38 \\
\hline
\end{tabular}

Inspired by the categorization of Hartel and Savolainen, the following graphic representations of mental models of personalized information spaces were distinguished: a café, a house, a cup of coffee, a landscape, a tree, a piece of mind, a computer, an octopus, a crossroads sign, a town, warmth (with 20 degree temperature), a skull as a spaceship, a human and a park (see examples in Figure 4).

For the sake of the reflexive thematic analysis, graphical and textual elements of the drawings were manually coded and, as it has been already mentioned, arranged in categories inspired by the concepts of information grounds, information horizons and small worlds. The elements of the people-places-information approach, along with the information activities highlighted in the drawings are a condition for functioning in the information space. The thematic analysis has also included socio-affective factors: norms, values and emotions, present in graphical representations of mental models of individual information spaces. 

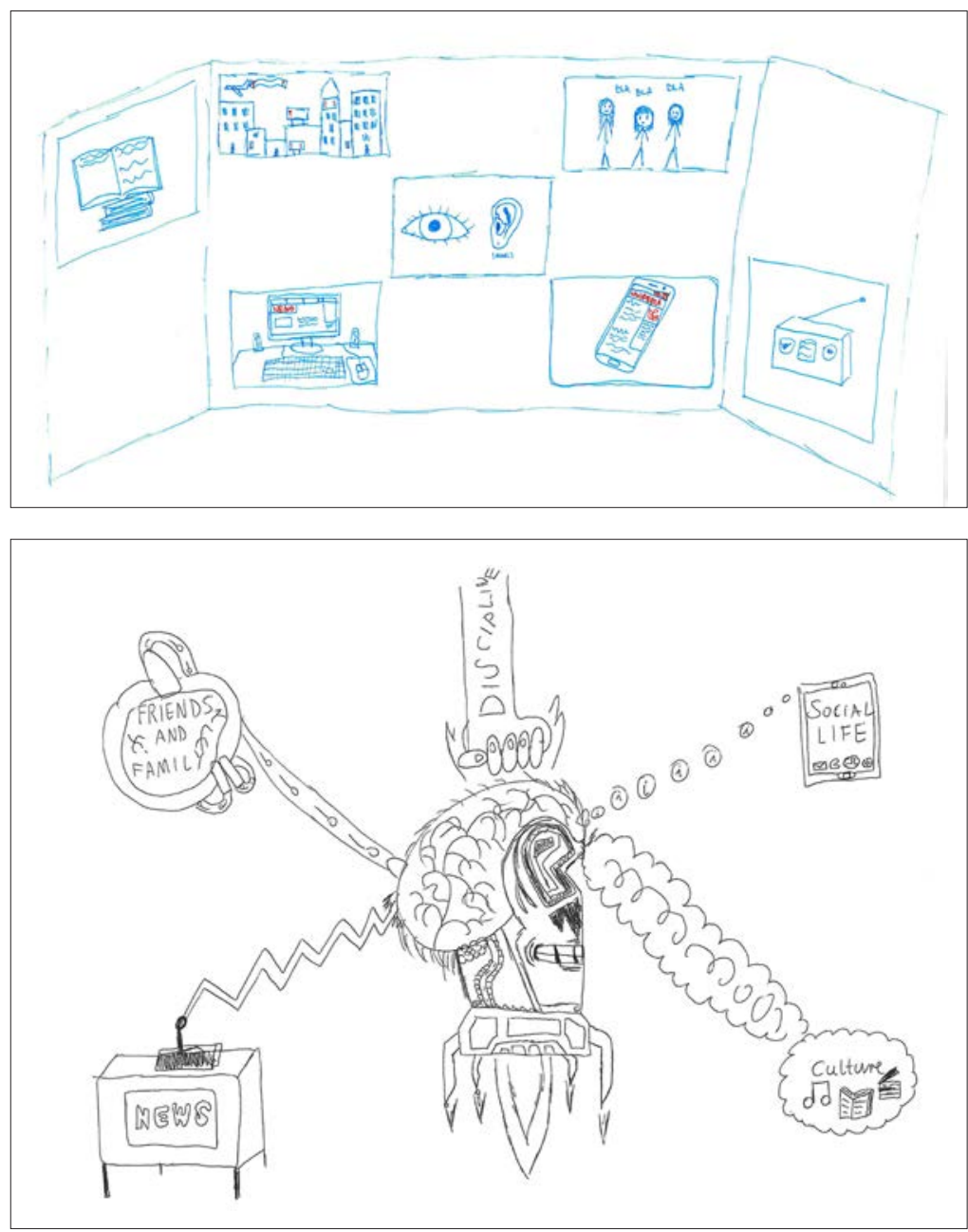

Fig. 4. Examples of abstract visual representation of individual information spaces

Codes related to the place component occur 222 times. As for the elements constituting the spatial dimension, we noticed 60 references to landscape, architecture and nature (mountains, pond, parks, forest, and even the beach), 58 to home (family, house architecture, idyllic image of the house, rooms), and 9 to specific names of places (e.g. United States of America, Kraków or Bieszczady).

Regarding people, there are 38 occurrences of codes concerning family (parents, mother, brother, sister), 64 - friends and acquaintances, and 44 - other people (e.g. co-workers, strangers, teachers). The participants used as many as 10 terms referring to the "I", first person singular, often figured as an individual and lonely being located in the center of the information space. The users also build strong emotional relationships with their animals and place them in the information space. There are nine occurrences concerning dogs, cats or horses. 
From the perspective of information, there have been 303 occurrences of codes relating to the content as such, information resources and information behaviors/processes taking place within personalized information spaces. As many as 237 times information sources were addressed, 39 of which were social media (e.g. Facebook, Twitter, Snapchat). There were 66 items concerned solely information activities, e.g. conscious information seeking and searching, information encountering, gathering, sharing.

As suggested by the information horizons theory, 160 elements related to social and affective factors characterizing the information space in everyday life have been distinguished. 60 items represented the affective aspect of information behavior. The pursuit for emotional well-being - identified with a sense of joy, happiness, comfort and love - dominated. The avoidance of negative emotions, as well as absence of fear and aggression, further characterized variously depicted information behaviors and relations within the personalized information spaces.

One hundred items referred to the social context, important norms and values held by the users, which shape information processes and influence the individual information space. Standards and values such as support, understanding, sense of security, beauty and even freedom were distinguished.

The thematic analysis and categorization of individual elements with a reference to the theoretical framework of the personalized information space in everyday life allowed us to distinguish the affective and social components, indicating that the respondents mostly operate within information grounds, which in turn can create small worlds; these affect formation of and functioning in information horizons and spaces. It is significant, that among the observed components of mental models of information spaces, many show very intense, emotional relationships connecting the respondents with their relatives, family and friends, and correlate them with undertaken various affective, cognitive and information processes. This aspect of mental models merits further research.

Thematic analysis in its reflexive version is not fully established in this paper. The results are "dangerously" close to the so-called domain summaries:

conceptualizing TA as simply a data reduction activity, where the purpose of analysis is to succinctly summarize the diversity of responses across the scope of a project (Braun et al., 2019, 846).

But the research described here makes for a first, necessary phase of our investigations. Furthermore, its primary goal has been meta-methodological, intended to establish a procedure rather than to make genuine discoveries.

Nevertheless, from the viewpoint of reflexive TA the central organizing concept is a mental model of individual information space in everyday life and the factors creating/ influencing it. The candidates for "real" themes, that is "reflecting a pattern of shared meaning, organized around a core concept or idea" (Braun et al., 2019, 845) are:

- pursuit of positive emotions/peace/safety as the main force shaping mental models of personalized information spaces;

- functioning within small worlds and repeated information grounds as a "surprising" means to ensure affective well-being;

- the occurrence of a full spectrum of forms and types of information behavior - but within the limited range of information sources (documentary and human). 


\section{Conclusions and limitations}

The advantages of empirical visual data, in particular the participant-generated, arts-based content, and the subsequent qualitative analysis of such data, in the information behavior field are as follows:

- building closer rapport with the study participants; activating creativity and inspiring questions; frequently it is a pleasure for the participants;

- cognitive access to hardly verbalized aspects of information behavior;

- comprehensive data, making rich, multi-dimensional, holistic empirical material, which may be analyzed in the reference to various theoretical frames and by different techniques, thus capturing diverse aspects and layers of "information reality", as in our case study;

- elimination of language and literacy barriers;

- flexibility; it is applicable to different populations and problems/questions (Greyson et al., 2017);

- "giving voice" primarily to the information users/research participants (human coefficient), not to the researcher;

- triangulation; it might be combined with more traditional, verbal data and elicitation techniques.

In addition, according to Hicks and Lloyd, the use of empirical visual data may facilitate information behavior research with specific or closed communities, where the use of more traditional research methods may be difficult, for example by unwillingness to cooperate or lack of communicative skills (Hicks \& Lloyd, 2018).

Among challenges, related to the analysis phase of research in particular, there are:

- it is labor-intensive and time-consuming;

- it requires an open mind and creativity from a researcher on the one hand, and scrupulousness, thoroughness on the other;

- most importantly, it is ambiguous and gives many potential options of analysis and interpretation, thus creating the need to leave precisely described "audit trail" to ensure intersubjective verifiability.

The analysis presented in this article, as it has already been stated, makes only for a first, descriptive, exploratory and tentative step of an ongoing research of individual, personalized information spaces and their representations. It gives a foundation for more in-depth and explanatory studies of information environments, horizons, and behaviors. For example, the presented thematic analysis has not been fully developed, which should and will be done in our future investigations. Furthermore, the discussion of the outcomes of our case study would be interesting, especially a comparison with similar projects by Hartel, Sonnenwald and other researchers. Finally, the critical literature review might be developed, by relating the HIB image-based studies to the wider context of visual methods in social sciences, as well as by reflection on the epistemological complexities of visual approach. 


\section{References}

Ayres, L. (2008). Thematic Coding and Analysis. In: L.M. Given (ed.), The Sage Encyclopedia of Qualitative Research Methods (867-868). Los Angeles, London, New Delhi, Singapore: Sage.

Babik, W. (2014). Ekologia informacji. Kraków: Wydaw. Uniwersytetu Jagiellońskiego.

Belkin, N.J., Kwasnik, B.H. (1986). Using Structural Representations of Anomalous States of Knowledge for Choosing Document Retrieval Strategies. In: F. Rabitti (ed.), Proceedings of the 9th Annual International ACM SIGIR Conference on Research and Development in Information Retrieval (11-22). New York: ACM.

Bergen, B. (2015). Embodiment, Simulation, and Meaning. In: N. Riemer (ed.). The Routledge Handbook of Semantics [online], (142-157). London: Routledge [5.05.2019], http://www.cogsci.ucsd. edu/ bkbergen/papers/ESM.pdf

Blatter, J.K. (2008). Case study. In: L.M. Given (ed.), The Sage Encyclopedia of Qualitative Research Methods (68-71). Los Angeles, London, New Delhi, Singapore: Sage.

Braun, V., Clarke, V. (2006). Using Thematic Analysis in Psychology. Qualitative Research in Psychology, 3(2), 77-101.

Braun, V., Clarke, V. (2012). Thematic Analysis. In: H. Cooper (ed.). APA Handbook of Research Methods in Psychology: Vol. 2. Research designs (57-71). Washington, DC: American Psychological Association.

Braun, V., Clarke, V., Hayfield, N., Terry, G. (2019). Thematic Analysis. In: P. Liamputtong (ed.), Handbook of Research Methods in Health Social Sciences (843-860). Singapore: Springer.

Burnett, G., Jaeger, P.R. (2011). The Theory of Information Worlds and Information Behaviour. In: A. Spink \& J. Heinström (eds.), New Directions in Information Behaviour (161-180). Bingley: Emerald Group.

Case, D.O, Given, L.M. (2016). Looking for Information. A Survey of Research on Information Seeking, Needs, and Behavior. Fourth edition. Bingley: Emerald Group Publishing Limited.

Chatman, E.A. (1991). Life in a Small World: Applicability of Gratification Theory to Information-Seeking Behavior. Journal of the American Society for Information Science, 42(6), 438-449

Chen, Y.-N. \& Ke, H.-R. (2014). A Study on Mental Models of Taggers and Experts for Article Indexing Based on Analysis of Keyword Usage. Journal of the Association for Information Science and Technology, 65(8), 1675-1694.

Cisek, S. (2010). Metoda analizy i krytyki piśmiennictwa w nauce o informacji i bibliotekoznawstwie w XXI wieku. Przeglad Biblioteczny, 78(3), 273-284.

Cisek, S. (2013). Metodologia jakościowa we współczesnej informatologii. Wybrane aspekty. Przeglad Biblioteczny, 81(3), 299-310.

Cole, Ch., Leide, J. (2003). Using the User's Mental Model to Guide the Integration of Information Space into Information Need. Journal of the American Society for Information Science and Technology, 54 (1), 39-46.

Cole, Ch., Lin, Y., Leide, J., Large, A., Beheshti, J. (2007). A Classification of Mental Models of Undergraduates Seeking Information for a Course Essay in History and Psychology: Preliminary Investigations into Aligning Their Mental Models with Online Thesauri. Journal of the American Society for Information Science and Technology, 58(13), 2092-2104.

Cox, A., Benson, M. (2017). Visual Methods and Quality in Information Behaviour Research: the Cases of Photovoice and Mental Mapping. Information Research [online], 22(2), [6.06.2019], http:// www.informationr.net/ir/22-2/paper749.html

Dervin, B. (2005). What methodology does to theory: Sense-making methodology as exemplar. In: K.E. Fisher, S. Erdelez \& L. McKechnie (eds.), Theories of information behavior (pp. 25-30). Medford, NJ: Information Today, Inc. 
Engelhardt, Y. (2002). The Language of Graphics: a Framework for the Analysis of Syntax and Meaning in Maps, Charts and Diagrams [online]. University of Amsterdam, Institute for Logic, Language and Computation, [6.06.2019], https://dare.uva.nl/search?identifier=c136c6f0-b987-4264-aeef-db053ea56a61

Fisher, K.E, Erdelez, S., McKechnie, L.E.F. (2005). Preface. In: K.E. Fisher, S. Erdelez \& L. McKechnie (eds.), Theories of Information Behavior (XIX - XXII). Medford, NJ: Information Today, Inc.

Fisher, K.E., Naumer, C.M. (2006). Information Grounds: Theoretical Basis and Empirical Findings on Information Flow in Social Settings. In: A. Spink \& C. Cole (eds.), New Directions in Human Information Behavior (93-111). Dordrecht: Springer.

Given, L.M., Saumure, K. (2008). Convenience Sample. In: L.M. Given (ed.), The Sage Encyclopedia of Qualitative Research Methods (124-125). Los Angeles, London, New Delhi, Singapore: Sage.

Greyson, D., O’Brien, H., Shankar, S. (2019). Visual Analysis of Information World Maps: an Exploration of Four Methods. Journal of Information Science, 1-17.

Greyson, D., O’Brien, H., Shoveller, J. (2017). Information World Mapping: A Participatory Arts-Based Elicitation Method for Information Behavior Interviews. Library and Information Science Research, 39(2), 149-157.

Hartel, J. (2014a). An Arts-Informed Study of Information Using the Draw-and-Write Technique. Journal of the Association for Information Science and Technology, 65(7), 1349-1367.

Hartel, J. (2014b). Information behaviour illustrated. Information Research. Proceedings of ISIC, the Information Behaviour Conference, Leeds, 2-5 September 2014: Part 1, (paper isic11) [online], [06.06.2019], http://www.informationr.net/ir/19-4/isic/isic11.html

Hartel, J. (2017). Information Behaviour, Visual Research, and the Information Horizon Interview: Three Ways. Information Research, 22(1), [online] CoLIS paper 1635, [6.06.2019], http://www. informationr.net/ir/22-1/colis/colis1635.html

Hartel, J., Oh, C., Nguyen, A.T. (2018). Teaching Information Behavior with the Information Horizon Interview. Journal of Education for Library and Information Science, 59(3), 67-79.

Hartel, J., Thomson, L. (2011). Visual Approaches and Photography for the Study of Immediate Information Space. Journal of the American Society for Information Science and Technology, 62(11), 2214-2224.

Hartel, J., Savolainen, R. (2016). Pictorial Metaphors for Information. Journal of Documentation, 72(5), 794-812.

Hicks, A. (2018). Developing the Methodological Toolbox for Information Literacy Research: Grounded Theory and Visual Research Methods. Library and Information Science Research, 40(3-4), 194-200.

Hicks, A., Lloyd, A. (2018). Seeing Information: Visual Methods as Entry Points to Information Practices. Journal of Librarianship and Information Science, 50(3), 229-238.

Holman, L. (2011). Millennial Students' Mental Models of Search: Implications for Academic Librarians and Database Developers. Journal of Academic Librarianship, 37(1), 19-27.

Johnson, D.J. (2003). On Contexts of Information Seeking. Information Processing and Management, 39(5), 735-760.

Johnson-Laird, P.N. (2010). Mental Models and Human Reasoning. PNAS Proceedings of the National Academy of Sciences of the United States of America, 107(43), 18243-18250.

Kerkhofs, R., Haselager, W.F.G. (2006). The Embodiment of Meaning. Manuscrito, 29(2), 753-764.

Kisilowska, M. (2011). Przestrzeń informacyjna jako termin informatologiczny. Zagadnienia Informacji Naukowej, 2(98), 35-52.

Kodama, C., St. Jean, B., Subramaniam, M., Taylor, N.G. (2017). There's a Creepy Guy on the Other end at Google!: Engaging Middle School Students in a Drawing Activity to Elicit Their Mental Models of Google. Information Retrieval Journal, 20(5), 403-432. 
Krishman, A., Jones, S. (2005). TimeSpace: Activity-Based Temporal Visualization of Personal Information Spaces. Personal and Ubiquitous Computing, 9(1), 46-65.

Le Louvier, K., Innocenti, P. (2019). The Information Mapping Board Game: a Collaborative Investigation of Asylum Seekers and Refugees' Information Practices in England, UK. Information Research [online], 24(1), [6.06.2019], http://www.informationr.net/ir/24-1/isic2018/isic1835.html Mitchell, C., Theron, L., Stuart, J., Smith, A., Campbell, Z. (2011). Drawings as Research Method. In: L. Theron, C. Mitchell, A. Smith \& J. Stuart (eds.). Picturing Research: Drawing as Visual Methodology (19-36). Rotterdam, The Netherlands: Sense Publishers.

Pollak, A. (2017). Visual Research in LIS: Complementary and Alternative Methods. Library and Information Science Research, 39(2), 98-106.

Savolainen, R. (2005). Everyday Life Information Seeking. In: K.E. Fisher, S. Erdelez \& L. McKechnie (eds.), Theories of Information Behavior (143-148). Medford, NJ: Information Today, Inc.

Savolainen, R. (2009). Small World and Information Grounds as Contexts of Information Seeking and Sharing. Library and Information Science Research, 31(1), 38-45.

Siegesmund, R. (2008). Visual Research. In: L.M. Given (ed.), The Sage Encyclopedia of Qualitative Research Methods (940-943). Los Angeles, London, New Delhi, Singapore: Sage.

Sonnenwald, D.H. (1999). Evolving Perspectives of Human Information Behavior: Contexts, Situations, Social Networks and Information Horizons. In: T.D. Wilson \& D.K. Allen (eds.), Exploring the Contexts of Information Behavior (176-190). London: Taylor Graham.

Sonnenwald, D.H. (2005). Information Horizons. In: K.E. Fisher, S. Erdelez \& L. McKechnie (eds.), Theories of Information Behavior (191-197). Medford, NJ: Information Today, Inc.

Sonnenwald, D.H., Wildemuth, B.M., Harmon, G.L. (2001). A Research Method to Investigate Information Seeking Using the Concept of Information Horizons: an Example from a Study of Lower Socio-Economic Students' Information Seeking Behaviour. The New Review of Information Behaviour Research, 2, 65-86.

Taylor, R.S. (1991). Information Use Environments. In: B. Dervin (ed.), Progress in Communication Sciences 10 (217-225). Norwood, NJ: Ablex.

Yu, L. (2011). Towards a Reconceptualization of the 'Information Worlds of Individuals'. Journal of Librarianship and Information Science, 44(1), 3-18.

Zhang, Y. (2008). The Influence of Mental Models on Undergraduate Students' Searching Behavior on the Web. Information Processing and Management 44(3), 1330-1345.

Zhang, Y. (2010). Dimensions and Elements of People's Mental Models of an Information-Rich Web Space. Journal of the American Society for Information Science and Technology, 61(11), 2206-2218.

\title{
Jakościowa analiza danych wizualnych w badaniach zachowań informacyjnych
}

\begin{abstract}
Abstrakt
Cel/Teza: Artykuł zawiera metodologiczną refleksję nad jakościową analizą wizualnych danych empirycznych jako procedurą poznawczą we współczesnych badaniach zachowań informacyjnych. Możliwość wdrożenia takiego podejścia została zweryfikowana na podstawie studium przypadku spersonalizowanych przestrzeni informacyjnych w życiu codziennym studentów pierwszego roku zarządzania informacją w roku akademickim 2018/2019.

Koncepcja/Metody badań: W dociekaniach zastosowano realistyczne stanowisko epistemologiczne, podejście jakościowe i opisowe oraz cztery metody/techniki badawcze: analizę i krytykę
\end{abstract}


piśmiennictwa, studium przypadku, rysunek jako narzędzie mapowania mentalnego i analizę tematyczną.

Wyniki i wnioski: Analiza danych wizualnych jest owocna poznawczo, umożliwia uchwycenie wielowymiarowej „rzeczywistości informacyjnej”, tak jak postrzegają ją użytkownicy (współczynnik humanistyczny). Jest jednak procedurą czasochłonną, wymagającą skrupulatności, solidnej autorefleksji badacza oraz pozostawienia jasno opisanej „ścieżki audytu” w celu zapewnienia wiarygodności i intersubiektywnej sprawdzalności dociekań.

Oryginalność/Wartość poznawcza: Artykuł skupia się na innowacyjnych procedurach badawczych, praktycznie nieomawianych w polskiej literaturze naukowej z zakresu informatologii. Integruje podejście wizualne $\mathrm{z}$ indywidualnymi przestrzeniami informacyjnymi, wpisując się $\mathrm{w}$ najnowsze trendy poznawcze w obszarze zachowań informacyjnych. Łączy również refleksję metateoretyczną z praktyką badawczą.

\section{Słowa kluczowe}

Analiza jakościowa. Analiza tematyczna. Badania wizualne. Dane wizualne. Metodologia. Metody oparte na sztuce. Modele mentalne. Przestrzenie informacyjne. Rysunki. Zachowania informacyjne.

SABINA CISEK, PhD, is a Senior Lecturer in the Institute of Information Studies, Faculty of Management and Social Communication, Jagiellonian University in Kraków, Poland. Her research focuses on human information behavior and literacy, qualitative methods in information science, philosophy and theory of information studies, and professional information services. Selected publications: Informacja (2017, published in: A. Żbikowska-Migoń, M. Skalska-Zlat (eds.), Encyklopedia książki); Diagnostyka kompetencji informacyjnych w miejscu pracy - technika incydentów krytycznych (2017, published in: R. Sapa (ed.), Diagnostyka w zarządzaniu informacją: perspektywa informatologiczna); Inspiracje i innowacje. Zarządzanie informacją w perspektywie bibliologii i informatologii (2016); Zawód infobroker. Polski rynek informacji (2015, co-editor A. Januszko-Szakiel).

Contact to the Author:

sabina.cisek@uj.edu.pl

Institute of Information Studies

Faculty of Management and Social Communication

Jagiellonian University in Kraków

prof. Stanistawa Łojasiewicza 4

30-348 Kraków

MONIKA KRAKOWSKA, PhD, is Associate Professor in the Institute of Information Studies, Faculty of Management and Social Communication, Jagiellonian University in Kraków, Poland. Her research interests are human information behavior, the social and affective aspects of information processes, and information culture. Selected publications: Information grounds in the eyes of the first-year information management students (2018, co-authors: S. Cisek, P. Korycińska; published in: Kurbanoğlu S., Boustany J., Špiranec S., Grassian E., Mizrachi D., Roy L. (eds), Information Literacy in the Workplace. ECIL 2017. Springer, Cham. https://doi.org/10.1007/978-3-319-74334-9_55); Diagnozowanie rozwiązań w zakresie zarządzania informacją w organizacji z perspektywy teorii information grounds i zachowań normatywnych (2017, published in: R. Sapa (ed.), Diagnostyka w zarządzaniu informacją: perspektywa informatologiczna); Zachowania informacyjne (2016, published in: W. Babik (ed.), Nauka o informacji).

Contact to the Author:

monika.krakowska@uj.edu.pl

Institute of Information Studies

Faculty of Management and Social Communication

Jagiellonian University in Kraków

prof. Stanistawa Łojasiewicza 4

30-348 Kraków 